\title{
Idäntutkimus 2021: Kutsu kirjoittajille
}

Haluaisitko kirjoittaa Idäntutkimukseen? Vuonna 2021 on tiedossa jälleen jännittäviä teemoja eri aihealueilta sekä yksi numero, jossa teema on vapaa.

1/2021, Pohjoinen kirjallisuus (deadline ollut 15.11.2020)

Teemanumero nostaa esiin Venäjän pohjoisten alueiden äänen, niiden oman kirjallisuuden ja kulttuurin, jotka keskusteluissa arktisista alueista usein jäävät ympäristökysymysten ja geopoliittisen valtapelin varjoon. Teemanumeron vierailevina toimittajana toimivat Tintti Klapuri ja Karina Lukin.

2/2021 Vapaa teema, deadline 1.2.2021

Vapaan teeman numeroon voi tarjota kirjoituksia eri tutkimusaloilta Idäntutkimuksen maantieteellisesti kattamaan alueeseen liittyen.

\section{3/2021 Teknologia, deadline 15.4.2021}

Teknologia on läsnä elämässämme monin tavoin ja monissa eri muodoissa. Perinteisesti käsite on liitetty teollisuuteen, koneisiin ja "koviin tieteisiin". Digitalisoitumisen myötä se liittyy myös entistä enemmän meidän kaikkien arkeen ja arjen toimintoihin. Samalla käsite on muuttunut abstraktimmaksi ja jopa näkymättömäksi - informaatioteknologian läsnäoloa ja vaikutusta elämäämme ei aina enää edes huomaa. Millä eri tavoilla teknologian voi nähdä liittyvän Venäjän tai itäisen Euroopan ihmisten elämään, työhön tai vapaa-aikaan, ennen ja nyt? Mitä tekemistä teknologialla on kulttuurin ja taiteen kanssa? Minkälainen on teknisten keksintöjen historia Venäjällä ja itäisessä Euroopassa? Entä minkälainen vaikutus teknologisella kehityksellä on ollut aluetutkijan arkeen ja tutkimustyön metodologiaan? Teemanumeroon voi tarjota artikkeleita, esseitä, kolumneja ja muita Idäntutkimukseen sopivia tekstejä erilaisista teknologiaan liittyvistä aiheista. Lähetä juttuehdotuksesi numeron vastaavalle toimittajalle Ira Österbergille [at] helsinki.fi tai päätoimittaja Katja Lehtisaarelle.

\section{4/2021 Rakkaus, deadline 15.8.2021}

Käsitteleekö Venäjään tai itäiseen Eurooppaan liittyvä tutkimuksesi rakkautta? Vuoden 2021 viimeinen numero on omistettu myönteisille tunteille ja erityisesti tunteista jaloimmalle, joka usein jää vähälle huomiolle tieteellisessä keskustelussa. Romanttinen rakkaus, perhesiteet, yhteisöllinen rakkaus, fanittaminen, rakkauden representaatiot taiteessa, rakkaus ideologiana näkökulmia aiheeseen on monta, kuuntelet vain sydämesi ääntä. Rakkaus-numeromme on avoin eri tieteenalojen ja metodien lähestymistavoille.

Kaikkia numeroitamme koskevat kirjoitusohjeet löytyvät sivuiltamme journal. fi/idantutkimus. Tervetuloa tarjoamaan 
juttuideoita! Julkaisemme muun muassa tieteellisiä artikkeleita, esseitä, kolumneja, väitöslektioita, kirja-arvioita, seminaariraportteja ja keskustelunavauksia. Pyydämme jättämään valmiit artikkelikäsikirjoitukset
Journal.fi-sivuston kautta; juttuideoista keskustellaksesi ota yhteyttä päätoimittaja Katja Lehtisaareen [at] helsinki.fi, toimituskunnan jäseniin tai teemanumeroiden toimittajiin. 